\title{
USE OF PHOTOCATALYTIC REDUCTION TO HASTEN PREPARATION OF CULTURE MEDIA FOR SACCHAROLYTIC CLOSTRIDIUM SPECIES
}

\author{
Romualdo S. Fukushima ${ }^{1 *}$; Paul J. Weimer²; Daniel A. Kunz ${ }^{3}$ \\ ${ }^{1}$ Faculdade de Medicina Veterinária e Zootecnia da Universidade de São Paulo, Pirassununga, SP, Brasil; ${ }^{2}$ U.S. Dairy Forage \\ Research Center, U.S. Department of Agriculture, Agricultural Research Service, and Department of Bacteriology, University of \\ Wisconsin - Madison, Madison, Wisconsin, United States of America; ${ }^{3}$ Department of Biological Sciences, University of North \\ Texas, Denton, Texas, United States of America.
}

Submitted: March 25, 2002; Returned to authors for corrections: August 22, 2002; Approved: February 07, 2003

\begin{abstract}
Cysteine is the preferred reducing agent used in the preparation of culture media for the growth of many strictly anaerobic microorganisms; however, redox potential reduction of cysteine is very slow, making it inconvenient if the medium is needed immediately or in large quantity. The time required to reduce culture medium containing resazurin (an indicator of reducing conditions) was dramatically shortened when the medium, after being injected with the reducing agent cysteine, was irradiated with incandescent light from a halogen lamp. Light intensity had an effect upon reduction time: tubes kept in the dark took more than $12 \mathrm{~h}$ to achieve the desired degree of anaerobiosis (measured spectrophotometrically by the bleaching of the indicator, resazurin) while tubes subjected to ordinary laboratory illumination were reduced in about $2 \mathrm{~h}$. When exposed to maximum light intensity (equivalent to a regular 100 watt bulb lamp) tubes could be made anaerobic in less than 20 min. Cysteine was essential for the bleaching of resazurin. Evidence that adequate anaerobiosis was achieved by light irradiation was provided by the fact that four Clostridium strains and one Thermoanaerobacter strain displayed similar growth (measured by lag time, growth rate, and extent of growth) in media reduced under high intensity light or under normal laboratory illumination.
\end{abstract}

Key words: anaerobiosis, culture medium, cysteine, light, resazurin

\section{INTRODUCTION}

The most widely accepted scenarios for the origin and evolution of life on earth posit that the primitive earth atmosphere was almost completely deprived of oxygen and the first organisms were anaerobic $(10,16,17)$. After the appearance of $\mathrm{O}_{2}$, a number of anaerobic environments were preserved and allowed the survival of microorganisms able to utilize substrates through fermentative and anaerobic respiratory processes (6). Anaerobic ecosystems remain widespread in the world and include soils, sediments, and human-managed process environments (landfills, anaerobic chambers used in breweries, sewage sludge digesters), as well as gastrointestinal tracts of man and animals $(4,7)$. Moreover, many anaerobic microorganisms are potential agents of several pathologies.

In vitro cultivation of many species of anaerobic microorganisms must be conducted in an environment that is not merely oxygen-free, but also highly reducing (low redox potential) $(5,7,9,10)$. Because of the vagaries of anaerobic medium preparation, there is a need to use dyes which allow visual assessment of the redox state of culture media. Resazurin (7-hydroxy-3H-phenoxazin-3-one 10-oxide; Fig. 1) is the most widely used indicator of reducing conditions in these culture media $(1,5,7,9)$. Methods aimed at eliminating dissolved $\mathrm{O}_{2}$ include sparging of culture media with $\mathrm{O}_{2}$-free gas (usually $\mathrm{CO}_{2}$ or $\mathrm{N}_{2}$ ) for several hours and addition of a chemical reducing

\footnotetext{
* Corresponding author. Mailing address: Faculdade de Medicina Veterinária e Zootecnia da Universidade de São Paulo, Av. Duque de Caxias Norte, 225. 13630-000, Pirassununga, SP, Brasil. Telephone: (+5519) 3565-4300, Fax: (+5519) 561-6215. E-mail: rsfukush@usp.br
} 
agent $(2,5,7,15)$. However, many anaerobic bacteria do not grow well in media reduced with strong reducing agents like sodium dithionite or sodium sulfide; some reasons for this include the formation of toxic intermediates and precipitation of essential metal ions. For these organisms, cysteine is the preferred reducing agent because of its low toxicity, but achieving reducing conditions (low redox potential) with cysteine is very slow, making it inconvenient if the medium is needed immediately or in large quantity.

Fukushima et al. (3) reported that a culture medium for anaerobic ruminal bacteria achieved the desired degree of anaerobiosis in considerably less time when exposed to high intensity light from a halogen lamp. The present work sought to verify that this same procedure could be employed in the preparation of a second type of anaerobic culture medium commonly used for the growth of nonruminal anaerobic bacteria.

\section{MATERIALS AND METHODS}

\section{Culture medium and light source}

Experiments were conducted in $18 \times 150 \mathrm{~mm}$ Balch-type anaerobic culture tubes sealed with flanged butyl stoppers (Bellco, Vineland, NJ) and aluminum crimp seals (Wheaton, Millville, NJ) (1). Culture medium used in all experiments was CM5 (cellulolytic medium) (18), containing resazurin (RNO) (Na salt, Sigma, St. Louis, MO, USA) as redox indicator at a concentration of $2.0 \mathrm{mg} / \mathrm{L}(\sim 6.8 \mu \mathrm{M})$. The medium was purged with $\mathrm{O}_{2}$-free $\mathrm{N}_{2}$ for 90 min $\left(\mathrm{N}_{2}\right.$ gas was rendered $\mathrm{O}_{2}$-free by passage through hot copper filings). Each tube received $0.4 \mathrm{~mL}$ of Cys from stock solutions of cysteine hydrochloride $(2.5 \% \mathrm{w} /$ $\mathrm{v}$, prepared under $\mathrm{N}_{2}$ ) via $\mathrm{N}_{2}$-flushed hypodermic syringes. Control tubes had no Cys but contained RNO; all tests were performed in triplicates.

Illumination of tubes was accomplished by placing two halogen lamps at distance of $38 \mathrm{~cm}$ from the tubes to be illuminated and angled $45^{\circ}$ to the benchtop in a shaded room to eliminate outdoor and hallway light. Tubes were illuminated at six different light intensities: 0 (dark), 10, 45, 90, 180 and $360 \mu \mathrm{E}$ $/ \mathrm{m}^{2} \times \mathrm{s}\left(\mathrm{E}=\right.$ Einstein; one $\mathrm{E}=6.02 \times 10^{23}$ photons $)$. Light intensity was measured with a model LI-189 quantum photometer (LICOR, Lincoln, NE). RNO reduction was determined every $2 \mathrm{~min}$ by measuring $\mathrm{A}_{600}$ with a Milton Roy model Spectronic 21 spectrophotometer. The effect of lamp type (incandescent or fluorescent) was tested at equivalent light intensities ( $10-12$ $\left.\mu \mathrm{E} / \mathrm{m}^{2} \times \mathrm{s}\right)$.

\section{Detection of dissolved oxygen}

In order to verify that the light-accelerated reduction of culture media containing RNO and Cys was followed by a concomitant disappearance in dissolved $\mathrm{O}_{2}$ content, $\mathrm{O}_{2}$ was measured with a Clark-type oxygen electrode (Rank Bros., U.K.) at $60^{\circ} \mathrm{C}$ containing $0.5 \mathrm{ml}$ of air-saturated medium and $\mathrm{RNO}(100$ $\mu \mathrm{g} / \mathrm{ml})$. The stimulation in $\mathrm{O}_{2}$-consumption upon adding Cys $(1.25 \mathrm{mg} / \mathrm{ml})$ was recorded in the absence (by covering with aluminum foil) and presence of incandescent light (Tensor ${ }^{\mathrm{R}}$ lamp, model 1500, Boston, MA, supplied 15 candlepower) placed 2 $\mathrm{cm}$ from the reaction cuvette.

\section{Microbial growth}

The following anaerobic microorganisms were grown (in quadruplicate): Clostridium butyricum 5001, Clostridium pasteurianum 5301, Clostridium perfringens 5003 and Thermoanaerobacter saccharolyticum B6A. Two experimental conditions were tested: after addition of all reagents, including Cys, culture tubes were either exposed to high intensity light $\left(370-380 \mu \mathrm{E} / \mathrm{m}^{2} \times \mathrm{s}\right)$ or to a lower intensity light in a laboratory fitted with ceiling-mounted overhead fluorescent bulbs, from which the measured light intensity on the benchtop varied slightly around a mean value of $\sim 10 \mu \mathrm{E} / \mathrm{m}^{2} \times \mathrm{s}$ (hereafter referred to as "regular laboratory illumination"). Microbial inoculation $(0.3 \mathrm{~mL}$ from a stock culture, injected into each tube, previously warmed to $39^{\circ} \mathrm{C}$ ) was performed immediately after medium reduction. Cultures were incubated in the dark at $39^{\circ} \mathrm{C}$ without shaking and were mixed by inversion just prior to each optical density reading at $540 \mathrm{~nm}\left(\mathrm{OD}_{540}\right)$.

Maximum specific growth rate constants ( $\mu_{\max }$ values) were calculated as the slope of the linear portion of a graph of $\ln$ $\mathrm{OD}_{540}$ versus time. Because of the difficulty of directly measuring the length of the lag time prior to onset of growth, lag time was estimated as:

Discrete lag time $=\left[\left(y\right.\right.$ intercept of $\ln \mathrm{OD}_{540}$ versus time regression line $)-\left(\ln \mathrm{OD}_{540}\right.$ at zero-time $\left.)\right] / \mu_{\max }$

\section{RESULTS AND DISCUSSION}

There was a dramatic effect of light intensity on culture media reduction (Fig. 2). Tubes kept in the dark as well as those exposed to regular laboratory illumination $\left(10 \mu \mathrm{E} / \mathrm{m}^{2} \times \mathrm{s}\right)$, did not achieve complete reduction during the experimental period of $60 \mathrm{~min}$. In other experiments (data not shown), tubes kept in the dark took more than $12 \mathrm{~h}$ to reduce whereas those under 10 $\mu \mathrm{E} / \mathrm{m}^{2} \times \mathrm{s}$, reduction was achieved after 2-3 h. When exposed to high intensity light $\left(180\right.$ and $\left.360 \mu \mathrm{E} / \mathrm{m}^{2} \times \mathrm{s}\right)$ complete medium reduction was achieved in less than $20 \mathrm{~min}$.

Fig. 3 shows the bilogarithmic plot between light intensity and the time required for complete medium reduction (determined spectrophotometrically). Because light intensities of 180 and $360 \mu \mathrm{E} / \mathrm{m}^{2} \times \mathrm{s}$ yielded similar effects on media reduction, there appears to be an upper limit on light intensity to achieve a maximum response and it is doubtful if light intensities over $360 \mu \mathrm{E} / \mathrm{m}^{2} \times \mathrm{s}$ will greatly accelerate medium reduction rate. This technique is very easy to use on a routine basis because an ordinary 100 Watt clear bulb lamp yields about $370 \mu \mathrm{E} / \mathrm{m}^{2} \times \mathrm{s}$ at $11-12 \mathrm{~cm}$ distance. 


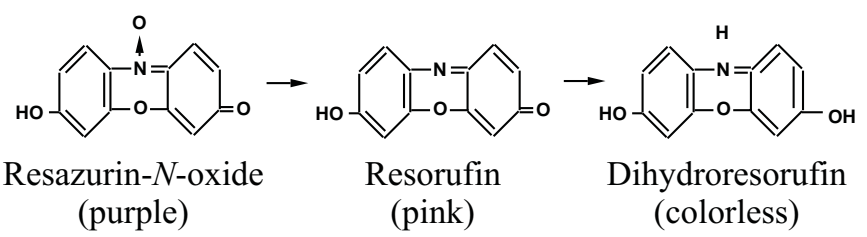

Figure 1. Structures of the oxidized, semireduced, and reduced forms of resazurin.

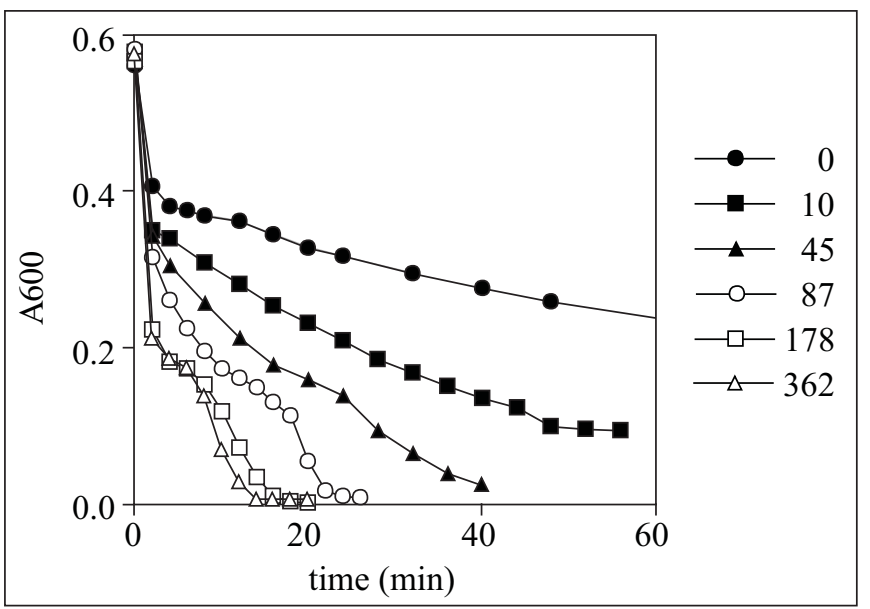

Figure 2. Effect of light intensity $\left(\mu \mathrm{E} / \mathrm{m}^{2} \times \mathrm{s}\right)$ on reduction of resazurin by cysteine.

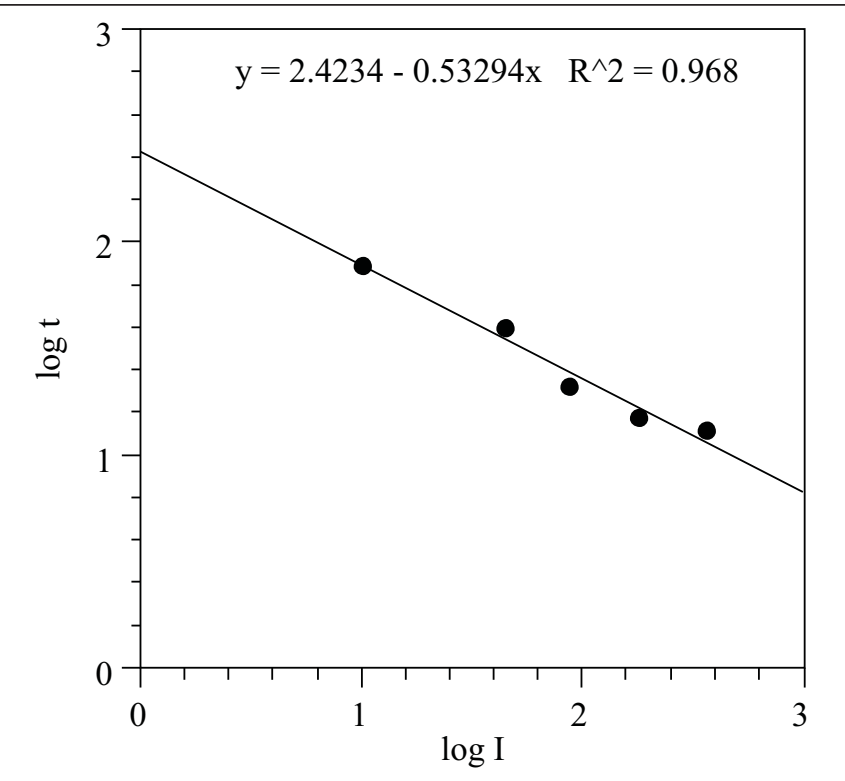

Figure 3. Effect of light intensity on time required to fully reduce resazurin.
No difference was observed between the type of light (incandescent or fluorescent), on time required to reduce the medium (Fig. 4). Light intensity tested was $10 \mu \mathrm{E} / \mathrm{m}^{2} \times \mathrm{s}$ and the tubes never reached total anaerobiosis during the experimental period of $60 \mathrm{~min}$; this light intensity was chosen because it mimics typical laboratory conditions. Both RNO and Cys were essential for the reaction to proceed. Cys apparently acts as an electron donor to RNO, resulting in the production of cystine and hydroresorufin, respectively (Fig. 1); during an oxidative reaction when two Cys molecules are linked together through a disulfide bond, two protons are released into the medium, and two electrons are transferred to available electron acceptors in the medium (11). While RNO was required for the photocatalytic effect, the exact mechanism of action by which it accelerates $\mathrm{RNO}$ reduction is unknown at the present moment.

Fig. 5 shows that in air saturated medium $\mathrm{O}_{2}$ uptake was strongly influenced by light. This demonstrates that the lightaccelerated reduction of culture media containing RNO and Cys was indeed followed by a concomitant disappearance in dissolved $\mathrm{O}_{2}$ content in the culture medium.

The illumination of culture tubes with high-intensity light for the purpose of reducing the time required for culture medium preparation exhibited no deleterious effects on the growth of four strains of Clostridium or T. saccharolyticum B6A. Growth (measured by lag time, specific growth rate, and maximum culture

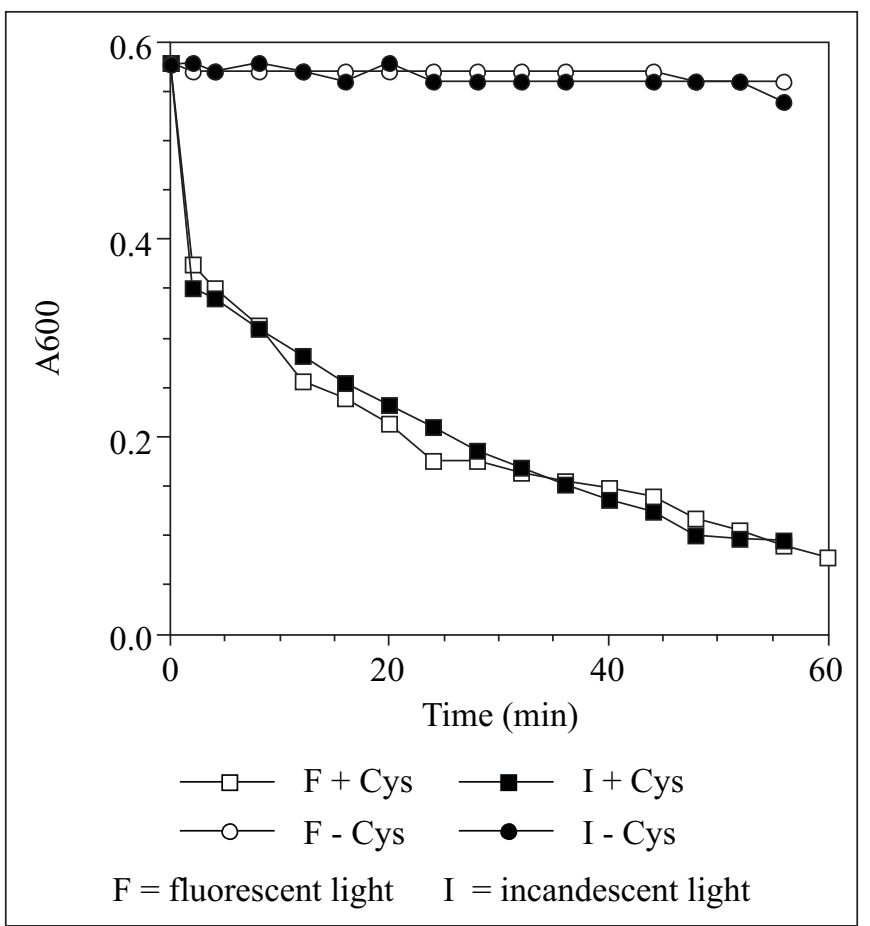

Figure 4. Effect of cysteine on reduction of resazurin under fluorescent or incandescent light at $10 \mu \mathrm{E} / \mathrm{m}^{2} \times \mathrm{s}$. 


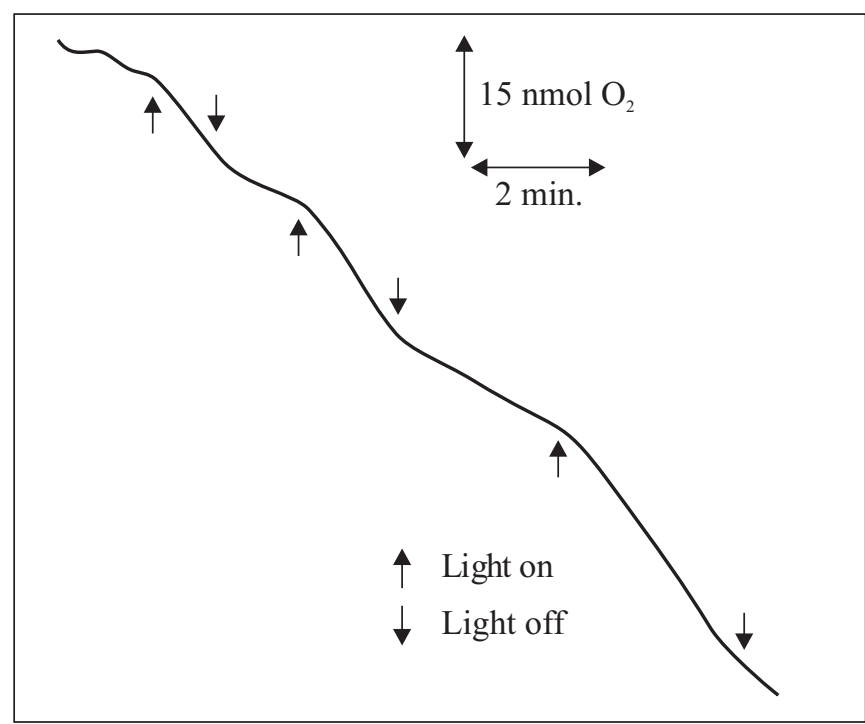

Figure 5. Effect of light on $\mathrm{O}_{2}$ uptake in medium containing RNO and Cys. Arrows indicate the times light was introduced or removed.

turbidity) was not significantly different $(\mathrm{P}>0.05)$ between media reduced rapidly under intense light and the same media reduced more slowly at regular laboratory illumination (Table 1).

The effect of light on resazurin-containing media was alluded to by Rasmussen and Nicolaisen (10), who noted that $2 \mathrm{~d}$ of dark incubation prevented the reduction of RNO in mammalian cells cultures that normally occurred during incubation under fluorescent light, (8 hours per day). Thus, they recommended restricted light exposure and minimal use of reducing agents with RNO for media intended for use as a viable cell indicator. Prütz et al. (13) noted that RNO was capable of efficiently catalyzing the photooxidation of reducing agents such as NADH, GSH and dopa. Okihana et al. (12) reported that high molecular weight soluble polymers produced by heating amino acids in a modified sea medium catalyzed the coupled reaction between dehydrogenation of NADH and reduction of RNO, and this reaction was accelerated by light. However, none of these workers exploited the photocatalytic reaction to accelerate the onset of anaerobic conditions.

We recently reported that acceleration of medium preparation by means of photocatalytic reaction with RNO had no adverse effect upon growth of several ruminal bacteria (3). The present report now generalizes this result to nonruminal bacteria. Thus, we recommend the use of this simple technique to shorten time spent in anaerobic media preparation.

\section{ACKNOWLEDGMENTS}

Appreciation is extended to "Fundação de Amparo à Pesquisa do Estado de São Paulo (FAPESP 98/14102-8)", under which the present research was conceived and conducted.

We thank J. Lindquist for providing cultures of Clostridium strains, and M.A. Cotta for providing a culture of Thermoanaerobacter saccharolyticum B6A.

\section{RESUMO}

\section{Uso de Redução Fotocatalítica para Acelerar Preparo de Meio de Cultura para Espécies Sacarolíticas de Clostridium}

A cisteína é o agente redutor preferido para o preparo de meios de cultura para muitos microrganismos estritamente anaeróbicos; no entanto, a ação redutora do potencial redox da cisteína é muito lenta, tornando-a inconveniente, para o uso imediato do meio ou em grande quantidade. $\mathrm{O}$ tempo requerido para reduzir o meio de cultura contendo resazurina (um indicador redox) foi bastante encurtado quando o meio, após ter sido injetado com o agente redutor cisteína, foi irradiado com luz incandescente proveniente de duas lâmpadas de halogênio. A intensidade da iluminação afetou o tempo gasto na redução: tubos mantidos no escuro alcançaram o nível desejado de anaerobiose (medido espectrofotometricamente pela descoloração do indicador, a resazurina) somente após $12 \mathrm{~h}$, enquanto os tubos mantidos sob iluminação, encontrada em

Table 1. Growth parameters for three Clostridium strains and one Thermoanaerobacter in media reduced at low or high intensity light ${ }^{1}$.

\begin{tabular}{|c|c|c|c|c|c|c|c|}
\hline \multirow[t]{2}{*}{ Bacterium } & \multirow{2}{*}{$\begin{array}{l}\text { Yeast extract } \\
(\mathrm{g} / \mathrm{L})^{2}\end{array}$} & \multicolumn{2}{|c|}{ Lag time $(\mathrm{h})$} & \multicolumn{2}{|c|}{ Specific growth rate $\left(\mathrm{h}^{-1}\right)$} & \multicolumn{2}{|c|}{ Maximum $\mathrm{OD}_{540}$} \\
\hline & & low / light & high / light & low / light & high / light & low / light & high / light \\
\hline C. butyricum 5001 & 2 & $\begin{array}{ll}3.3 \quad( \pm 0.5) \\
\end{array}$ & $3.0 \quad( \pm 1.2)$ & $0.49( \pm 0.06)$ & $0.46( \pm 0.06)$ & $1.18( \pm 0.05)$ & $1.17( \pm 0.03)$ \\
\hline C. pasteurianum 5301 & 2 & $0.08( \pm 0.03)$ & $0.25( \pm 0.30)$ & $0.56( \pm 0.02)$ & $0.56( \pm 0.03)$ & $1.41( \pm 0.01)$ & $1.42( \pm 0.03)$ \\
\hline C. perfringens 5003 & 5 & $1.76( \pm 0.93)$ & $0.93( \pm 0.72)$ & $0.27( \pm 0.01)$ & $0.27( \pm 0)$ & $0.70( \pm 0.04)$ & $0.79( \pm 0.06)$ \\
\hline T. saccharolyticum B6A & 1 & $1.22( \pm 0.24)$ & $1.09( \pm 0.06)$ & $0.61( \pm 0.01)$ & $0.61( \pm 0.03)$ & $1.19( \pm 0.03)$ & $1.21( \pm 0.04)$ \\
\hline
\end{tabular}

${ }^{1}$ Results are mean values of 4 tubes $( \pm$ S.E.M. $) ;{ }^{2}$ Cultures were grown in CM $5+$ glucose $(10 \mathrm{~g} / \mathrm{L})$ and indicated amount of yeast extract. 
um laboratório comum, levaram cerca de $2 \mathrm{~h}$. Por outro lado, os tubos irradiados com máxima intensidade de luz (equivalente a uma lâmpada normal de 100 watt) tornaram-se totalmente incolores em menos de $20 \mathrm{~min}$. A cisteína mostrou-se ser um reagente indispensável para que a redução da resazurina ocorresse. Evidências de que a anaerobiose do meio de cultura, acelerada pela alta irradiação de luz artificial, foi alcançada, foram fornecidas pelo fato de que quatro cepas de Clostridium e uma de Thermoanaerobacter mostraram crescimento similar (medido através de tempo de duração da fase lag, velocidade de crescimento e crescimento máximo) em meio de cultura reduzido através de exposição a alta intensidade luminosa ou em meio preparado de maneira convencional.

Palavras-chave: anaerobiose, cisteína, luz, meio de cultura, resazurina.

\section{REFERENCES}

1. Balch, W.E.; Wolfe, R.S. New approach to the cultivation of methanogenic bacteria: 2-mercaptoethanesulfonic acid (HS-CoM)dependent growth of Methanobacterium ruminatium in a pressurized atmosphere. Appl. Environ. Microbiol., 32: 781-791, 1976.

2. Bryant, M.P. Commentary on the Hungate technique for culture of anaerobic bacteria. Am. J. Clin. Nutr., 25: 1324-1328, 1972.

3. Fukushima, R.S.; Weimer, P.J.; Kunz, D. Photocatalytic interaction of resazurin $N$-oxide with cysteine optimizes preparation of anaerobic culture medium. Anaerobe, 8: 29-34, 2002.

4. Hobson, P.N. The rumen microbial ecosystem. Elsevier, New York, $1988,527 \mathrm{p}$.
5. Holdeman, L.V.; Cato, E.P.; Moore, W.E.C. Anaerobe laboratory manual, $4^{\text {th }}$ ed., Virginia Polytechnic and State University, Blacksburg, VA, 1977, p. 123.

6. Huber, C.; Wächtershäuser, G. Peptides by activation of amino acids with $\mathrm{CO}$ on $(\mathrm{NiFe}) \mathrm{S}$ surfaces: implications for the origin of life. Science, 281: 670-672, 1998 .

7. Hungate, R.E. The anaerobic, mesophilic, cellulolytic bacteria. Bacteriol. Rev. 14: 1-49, 1950.

8. Hungate, R.E. The rumen bacteria. In: Hobson, P.N. (ed.). The rumen microbial ecosystem. Elsevier, New York, 1988, p. 1-19.

9. Impey, C.S.; Phillips, B.A. Maintenance of anaerobic bacteria. In: Kirsop, B.E.; Snell, J.J.S. (eds.). Maintenance of microorganisms. Academic Press, New York, 1984, p. 47-54.

10. Margulis, L. Archaeal-eubacterial mergers in the origin of Eukarya: Phylogenetic classification of life. Proc. Nat. Acad. Sci. USA, 93: 1071-1076, 1996.

11. Nelson, D.L.; Cox, M.M. Lehninger Principles of biochemistry. $3^{\text {rd }}$ ed., Worth Publishers, New York, 2000, 1152p.

12. Okihana, H. Formation and catalytic activity of high molecular weight soluble polymers produced by heating amino acids in a modified sea medium. Origins of Life, 12: 153-163, 1982.

13. Prütz, W.A.; Butler, J.; Land, E.J. Photocatalytic and free radical interactions of the heterocyclic $N$-Oxide resazurin with NADH, GSH, and Dopa. Arch. Biochem. Biophys., 327: 239-248, 1996.

14. Rasmussen, E.S.; Nicolaisen, G.M. Stability of resazurin in buffers and mammalian cell culture media. In Vitro Mol. Toxicol., 12: 195$202,1999$.

15. Stewart, C.S.; Bryant, M.P. The rumen bacteria. In: Hobson, P.N. (ed.). The rumen microbial ecosystem. Elsevier, New York, 1988, p. 21-65.

16. Wächtershäuser, G. The origin of life and its methodological challenge. J. Theor. Biol., 187: 483-494, 1987.

17. Wächtershäuser, G. Life as we don't know it. Science, 289: 13071308,2000

18. Weimer, P.J.; Wagner, L.W.; Knowlton, S.; Ng, T.K. Thermophilic anaerobic bacteria which ferment hemicellulose: characterization of organisms and identification of plasmids. Arch. Microbiol., 138: 3136,1984 . 